\title{
企業の決算短信PDFからの業績要因の抽出 Extraction of causal information from PDF files of the summary of financial statements of companies
}

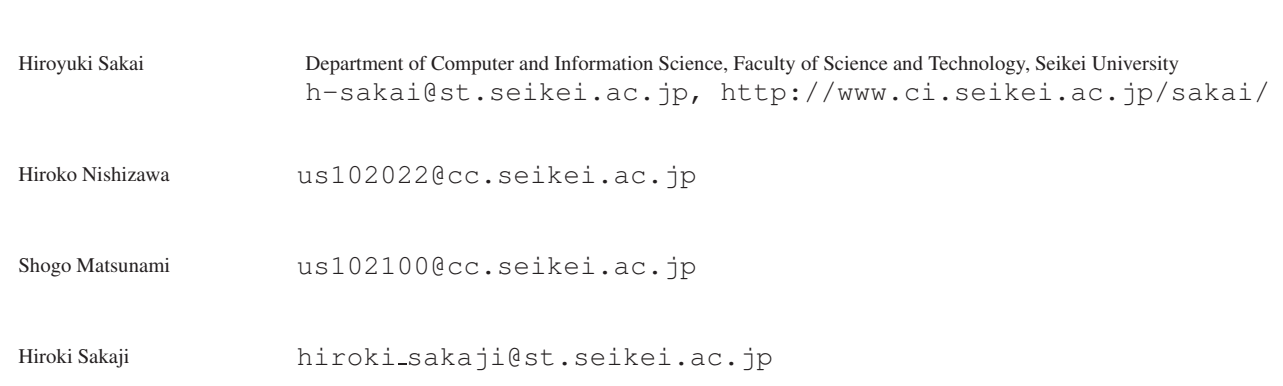

keywords: summary of financial statements of company, causal information, information extraction, text mining

\section{Summary}

In this paper, we propose a method of extracting causal information from PDF files of the summary of financial statements of companies, e.g., "The sales of smart phones was expanded continually". Cause information is useful for investors in selecting companies to invest. We downloaded 106, 885 PDF files of the summary of financial statements of companies from Web pages of the companies automatically. Our method extracts causal information from the PDF files by using clue expressions (e.g., "was expanded") and keywords relevant to a company. The clue expressions are extracted from the PDF files of the summary of financial statements of companies and articles concerning business performance of companies automatically. We developed the search system which is able to retrieve causal informations extracted by our method. The search system shows causal information containing a keyword inputted by users, and the summary of financial statements containing the retrieved causal information. We evaluated our method and it attained $83.91 \%$ precision and $55.04 \%$ recall, respectively. Moreover, we compared our method with Sakai et al's method originally proposed for extracting causal information from financial articles concerning business performance of companies and experimental results showed that our method outperforms Sakai et al's method.

1.は じめに

近年, 証券市場における個人投資家の比重が増大して おり，個人投資家に対して投資判断の支援をおこなう技 術の必要性が高まっている. 兴のため, 人工知能分野の 手法や技術を，金融市場における樣々な場面に応用する ことが期待されており，例えば，膨大な金融情報を分析 して投資判断の支援をする技術が注目されている．光の 一例として, 日本銀行が毎月発行している「金融経済月 報」や新聞記事をテキストマイニングの技術を用いて，経 済市場を分析する研究などが盛んに行われている[和泉 11 , 藏本 13 , 酒井 13].

投資家にとって，企業の業績に関する情報を収集する ことは重要であるが, 実際の業績に関する情報だけでな く, 兴の業績要因が重要である [Sakai 08, Sakai 09, 酒井 13]. なぜなら, 業績回復の要因が, 光の企業の主力事業 が好調であることであったならば株価への影響は大きい が, 株式売却益の計上などの特別利益の計上が要因であ るならば株価への影響は軽微であるからである . 例えば，
パナソニックは 2012 年度上期の連結業績を 2012 年 10 月 31 日に発表し，売上高は前年同期比 $9.20 \%$ 減の 3 兆 6,381 億円, 営業利益は $83.50 \%$ 増の 873 億円であった が, 当期純損失は前年の 1,361 億円の赤字から 5,490 億 円悪化し 6,851 億円の赤字となった . 当時の津賀一宏社 長は 2012 年 10 月 31 日の決算会見で「今回の大幅な業 績の下ぶれれ根本的な原因は, 本業の不振にある」とも 語った*1 . 決算内容は営業黑字を確保しているが, 社長の 「本業の不振」の発言が嫌気され, パナソニックの 2012 年 11 月 1 日の株価は, 前日から 100 円 (19.46\%) 下げ てストップ安となった .

しかしながら, 証券市場の上場企業数は東京証券取引 所の上場企業だけでも 2014 年 8 月 1 日現在, 3432 社 と多いうえに*2, 近年では年に 4 回 , 決算発表がある*3. さらに, 大幅な業績の修正を行う場合にも業績修正発表

\footnotetext{
*1 http://www.panasonic.co.jp/ir/vision/pdf/20121031_vision_note_j.pdf $* 2$ http://www.tse.or.jp/listing/companies/

*3 1 年を 4 期に分け, 3 か月ごとに企業が公表する. 平成 15 年 より全上場企業に義務づけられている
} 
を行う必要があるため, 人手によって多くの企業の業績 要因を取得するのには多大な労力を要する. 兴のために 酒井らは, 経済新聞記事から企業の業績発表記事を抽出 し, 兴の中から業績要因 (例えば「主力の半導体製造装 置の受注か好調」) を抽出する手法を提案した [Sakai 08] . そとて, 経済新聞記事の業績発表記事から抽出した業績 要因表現を対象とした検索システムを作成した [酒井 13] . しかし, 酒井らの研究は以下のような問題点がある.

・経済新聞記事に掲載される企業の業績発表記事を対 象としているため, 著作権の問題で, 作成した検索 システムを一般には公開できない .

・経済新聞記事に掲載される企業の業績発表記事は， 上場企業のなかでも概ね大企業に限られており，全 ての上場企業の業績発表記事が掲載されない．

・通常は企業が決算発表を行った後に業績発表記事が 経済新聞などに掲載されるため, 実際の決算発表と のタイムラグが生じ，個人投資家に対する投資判断 支援の観点からも実用性に乏しい .

乥こで, 本研究では, 企業か鄴績発表を行った直後に, 企 業のWeb サイト等で一般に公開されている企業の決算 短信*4 に着目する . 企業の決算短信は PDF 形式で企業の Web サイト等て配布され，誰でも閲覧ができる，光して， 弚の中には業績の数字データと共に, 文書にて業績要因 も記述されている.この決算短信PDFから，業績要因を 抽出することができれば，上記の 3 つの欠点を解決する ことができる

本研究では, 決算短信 PDF から業績要因を含む文を 自動的に抽出することを目的とする。例えば，エプソン の決算短信 PDF から「プロジェクターは, 南米・中国・ インドなどの新興国を中心とした教育市場向けか堅調に 推移したほか , 大型スポーツイベントを控えた欧州では ホーム用途で需要の拡大が見られました」のような文を 抽出する . 光して, 企業のWeb サイトにて配布されてい る決算短信 PDF を収集し，兴の中から業績要因を含む 文を抽出することにより，全ての上場企業を対象とした， 一般公開できるような業績要因の検索システムの実現が 可能になる .

本論文の第 2 章では, まず, 関連研究について述べ, 関 連研究と本研究の違いや本手法の特徵について述べる.第 3 章では, 企業 Web ページから決算短信 PDF ファイル がダウンロードできるページを自動的に判定し，決算短 信 PDF ファイルを自動的に取得する手法について述べ る.第4章では, 取得した決算短信PDF から業績要因を 抽出する手法について述べる.第 5 章では, 本手法の実 装について述べる.第6 章では本手法の評価について述 ベ, 第 7 章では評価結果を考察する。

\footnotetext{
$* 4$ 決算短信とは, 上場会社が決算発表及び四半期決算発表を行 う際に, 決算内容の要点をまとめた書類の名称である.記者ク ラブが決算発表内容の標準化を目的として上場会社に要請した ことから始まり，現在は取引所が樣式を定め [東京 14] , 全て の上場会社が作成することになっている。
}

\section{2. 関 連 研 究}

関連研究として, 酒井らは, 企業の業績発表記事から 業績要因を抽出し [Sakai 08], さらに, 抽出した業績要 因に対して業績に対する極性（「ポジティブ」「ネガティ ブ」）を付与する手法を提案した [Sakai 09] . 例えば，業 績要因「ソフト販売の収益が寄与する」に対しては「ポ ジティブ」「繊維部門の不振か響く」に対しては「ネガ ティブ」のラベルを付与する . 酒井らの手法 [Sakai 08] では, 1つの業績発表記事からは複数の業績要因か抽出 される，㚇の中から抽出される業績要因の中には，例え ば「独禁法関連費用を営業外費用に計上」のような，事 業と関連性の低い, 弚れほど重要ではない業績要因も存 在している. 兴のため, 酒井らは抽出される複数の業績 要因から重要な業績要因を自動的に抽出する手法を提案 している [酒井 13] . しかし，これらの研究は1章の「は じめに」で述べたような欠点がある，弚れに対して，本 研究は, 企業のWeb ページで一般に公開されている決算 短信PDF から業績要因を抽出する。これにより，決算短 信から抽出した業績要因を対象とした検索システムを構 築し，一般に公開することができる．さらに，上場企業 であれば決算短信は企業 Web 上で公開しているので, 経 済新聞に業績発表記事が掲載されないような企業の業績 要因をも抽出し, 検索システムの検索対象にできる .

酒井らの業績要因抽出手法 [Sakai 08] では, 業績要因 を「共通頻出表現」と「手がかり表現」の2つの表現を 使用して抽出した .ここで, 手がかり表現を業績要因と なる状況, 状態, 変化を表す用言的な表現と定義し, 共 通頻出表現を同一文中で手がかり表現と共起する，業績 要因の特徵を表す体言的な表現と定義した . 例えば，業 績要因「主力の半導体製造装置の受注が好調」では, 手 がかり表現が「が好調」であり，共通頻出表現は「半導 体製造装置」「受注」である.酒井らの業績要因抽出手法 では, 数多くの「手がかり表現」と「共通頻出表現」を 業績発表記事から自動的に獲得し，光れらを使用するこ とで業績要因を抽出した . 本手法では, 酒井らの手法を 使用して決算短信 PDF から自動的に獲得した「手がかり 表現」を使用して, 決算短信 PDF から業績要因を抽出す る.しかし, 酒井らの手法を, 兴のまま決算短信PDFに 対して適用せず，一度，業績発表記事から獲得した手が かり表現を使用して決算短信PDFから業績要因を含む文 を抽出し，㚇の抽出された業績要因を含む文の集合から， 新たに手がかり表現を獲得する．弚の理由は以下のとお りである .

酒井らの手がかり表現獲得手法は, 最初に少数の手が かり表現を人手で与え, 弚こからブートストラップ的に 手がかり表現を増やしており，いわゆるブートストラッ ピング法 [Yarowsky 95, Abney 04] と呼ばれる手法であ る. 产のため, 途中で手がかり表現として適切ではない 表現が獲得されると, 弚の表現から,ささらに不適切な表 
現が獲得されてしまう. 業績発表記事の場合は , 業績要 因を含む文の割合が多いため, 手がかり表現として不適 切な表現か獲得される可能性は低いが, 決算短信PDFに は業績要因を含む文の割合は少ない，兴のため, 決算短 信PDFの全ての文から手がかり表現を獲得すると，不適 切な表現が獲得される. 兴のため, 一度, 酒井らの手法 で業績発表記事から手がかり表現を抽出し，光れを使用 して決算短信 PDF から業績要因を含む文を抽出し，谷の 中から，新たな手がかり表現を獲得する．また，抽出対 象の企業と関連のあるキーワードを決算短信PDF から獲 得し,「共通頻出表現」ではなく，弚れらを使用して決算 短信PDF から業績要因を抽出する .

和泉らは,日銀が発行している「金融経済月報」を用い， 国債市場の分析を行っている[和泉 11] . 文献 [和泉 11] の 研究では, 共起解析 (co-occurrence analysis) , 主成分分 析 (principal component analysis) , 回帰分析 (regression analysis) からなるCPR 法を提案し，テキストを解析す ることで国債市場の分析を行っている。ささに，蔵本ら は文献 [和泉 11] の研究をさらに発展させ , 入力テキス 卜を新聞記事として，長期的な株式市場の分析を行って いる[藏本 13] . Sakaji らは, 景気動向について述べた経 済新聞記事を対象に, 景気が上がるか下がるかの根拠表 現を抽出し，抽出した根拠表現に対して極性 (ポジティ ブ , ネガティブ) を付与する手法を提案している [Sakaji 08] . Milea らは, 欧州中央銀行が発行している報告書か ら Fuzzy Grammar Fragment を抽出し，兴れに基づき， MSCI ユーロ・インデックスを予測（上向き，もしくは， 下向きに推移するかどうか) している [Milea 10] . Koppel らは, 企業に関する記事が, 弚の企業の株洒に影響を与え るかどうかを判別する手法を提案している [Koppel 04] . Lavrenko らは, 企業に関する記事内容によって引き起こ される株価の動きを予測するための手法を提案している [Lavrenko 00] . これらの研究では, 企業の株価データな どの基礎情報を用いず，日銀の金融経済月報や景気動向 記事のような新聞記事といったテキスト情報を用い，将 来の市場予測を行っている。しかし，これらの研究は，株 価や債券市場に影響を与える原因に関する記述を抽出し ているものではなく，本研究とは目的が異なる．光れに 対して, 本研究では, 決算短信PDFから業績要因を自動 的に抽出することで, 業績を達成した原因を企業の決算 短信の中から取得することができる .

\section{3. 企業 Web ページからの決算短信 PDF ファ イルの取得}

多くの企業の決算短信PDF を収集して業績要因を抽出 するために，まず，企業 Web ページから決算短信 PDF ファイルを自動で取得する手法について述べる，決算短 信 PDF ファイルは, 企業の Web ページで公開されてい るPDFファイルを全てダウンロードし, 兴の中から決算
短信 PDF ファイルを判定しても取得することは可能であ る.しかし, PDF ファイルは容量が大きいため, 兴のよ うな方法では企業のWebサーバーに対して大きな負担が かかる . また , 決算短信 PDF ファイルが更新される度に 全てのPDF ファイルをダウンロードする必要が生じるた め, 頻繁な情報更新ができなくなる. 弚こで本研究では, 企業の Web ページの中から決算短信 PDF ファイルがダ ウンロードできるIR 情報ページ*5を識別し，兴のページ の PDF ファイルのみをダウンロードすることで, 必要の ないPDFファイルをダウンロードすることを避ける．以 下に, 手法の概要を示す.

Step 1： 企業 Web ページを収集し，企業 Web ページに おいて決算短信 PDF ファイルがダウンロードできる IR 情報ページを，決算短信 PDF ファイルがダウン ロードできるかどうかを判定基準として人手にて判 定する .

Step 2: Step 1 で判定した企業 Web ページにおける IR 情報ページを学習データの正例とし, 弚れ以外の企 業 Web ページを負例として, サポートベクトルマ シンで分類器を生成し, 全ての企業 Web ページを決 算短信 PDF ファイルがダウンロードできる IR 情報 ページと光うでないページに分類する．

Step 3: Step 2 で識別した , 決算短信 PDF ファイルが ダウンロードできる IR 情報ページの URL から，よ く出現する URL の文字列を抽出する．

Step 4: Step 2 で識別した IR 情報ページの URL に加え， Step 3 で抽出した文字列を含む URL の Web ページ から , ダウンロードできる PDF ファイルを全てダウ ンロードする．

Step 5: ダウンロードした PDF ファイルのテキスト情 報から，決算短信 PDF ファイルを選別する .

Step 1 においては，3,821 社の企業 Web ページ*6を収集 した．また，Step 1 にて，Step 2 で使用する学習用デー タとして, 決算短信 PDF ファイルがダウンロードでき る IR 情報ページを， 155 の企業から人手で 200 ページ 集めた .この 200 ページをサポートベクトルマシンにお ける学習用データの正例とする．負例には，IR 情報ペー ジ以外のページから，正例と同数の 200 ページを集めた . Step 2 におけるサポートベクトルマシンによる識別のた めの素性として, 学習用データとして用意した Web ペー ジ (正例 200 ページ , 負例 200 ページ) に含まれる名詞 を使用した . また ，素性値としてはWebページに含まれ る素性の頻度 , カーネルには線形カーネルを使用した 。

\footnotetext{
*5 インベスター・リレーションズ (IR) とは, 企業が投資家に 向けて経営状況や財務状況，業績動向に関する情報を発信する 活動のことであり，IR 情報ページとは，企業 Web サイトにて， 経営状況や財務状況, 業績動向に関する情報 (IR 情報) が記 述してある Web ページのことである

*6 東証以外の証券取引所にて単独上場している企業や, 持株会 社への移行や統合などで非上場となった企業も含む
} 
Step 3 は, より多くの企業 Web ページから決算短信 PDF ファイルをダウンロードするために行う . 予備実験 として, Step 2 で生成された分類器を使用して, 47 企業 の企業 Web ページにおいて決算短信 PDF ファイルがダ ウンロードできるIR 情報ページを識別した . 谷の結果， 41 企業において正しく IR 情報ページを識別し, 精度は $87.20 \%$ となった．しかし，6 企業において IR 情報ぺー ジを識別できず, 弚の企業の決算短信 PDF ファイルをダ ウンロードできなかった．予備実験より，Step 2 の処理 のみでは決算短信 PDF ファイルをダウンロードできない 企業があることが分かつたため, Step 3 の処理を行う . 具 体的には, Step 2 で生成された分類器を全ての企業 Web ページにおいて適用し, 決算短信 PDF ファイルがダウン ロードできる IR 情報ページと判定された Web ページの URL を得る．次に, 得られたURL を゙/”で区切り，区 切られた文字列の頻度を得る. 光して, 頻度が高い文字 列を IR 情報ページの URL によく出現する文字列とし， 兴の文字列を含んでいる URL からダウンロードできる PDF ファイルを全てダウンロードする . 以下に , 上記の 手法で取得した，IR 情報ページのURL によく出現する 文字列をいくつか示す.

ir, library, company, investor, calendar.html, financial, library.html, calendar, investors, finance, IR, report, tanshin.html, irinfo, kessan

Step 4 にてダウンロードした PDF ファイルには , 決算短 信以外のPDF ファイルも多く含まれている. 弚こで, ダ ウンロードした PDF ファイルのテキスト情報から , 決算 短信 PDF ファイルを選別する.具体的には, PDF ファイ ルからテキスト情報を抽出 ${ }^{* 7}$ し, 最初から 10 行以内*8に 「決算短信」の文字列を含むものを, 決算短信 PDF ファ イルとして選別する.なお, 決算短信の樣式は証券取引 所によって定められている，弚のため, 題目に「決算短 信」という文字列が必ず含まれる。

上記の手法にて, 最終的に , 3,821 社の企業 Web ペー ジから 106, 885 個の決算短信 PDF ファイルを取得した . なお，Step 2 までの手法で識別した IR 情報ページからダ ウンロードできた決算短信 PDF ファイルは 97, 036 個で あり, Step 3 , Step 4 の処理を行うことで, より多くの決 算短信 PDF ファイルをダウンロードすることができた .

\section{4. 決算短信 PDF からの業績要因抽出}

本章では, 企業 Web ページから取得した決算短信 PDF から，業績要因を含む文を自動的に抽出する手法につい て述べる.以下に, 手法の全体的な概要を示す。

*7 pdftotext を使用.

*8100 個の決算短信 PDF において, 1 ページ目の上から平均 で 1.56 行目に題目が記述されていたが, 余裕をみて , 10 行と 設定した .
Step 1： 酒井らの手法を使用して，業績発表記事から手 がかり表現を獲得する

Step 2: 決算短信 PDF から，光の企業にとって重要な キーワードを抽出する．

Step 3: Step 1 で獲得した手がかり表現と Step 2 で抽 出した，光の企業にとって重要なキーワードを使用 して, 決算短信 PDF から業績要因を含む文を抽出 する .

Step 4: Step 3 で抽出した業績要因を含む文の集合から， 酒井らの手法を再度 , 使用して, 手がかり表現を獲 得する.

Step 5: Step 1 と Step 4 で獲得した手がかり表現と， Step 2 で抽出した, 弚の企業にとって重要なキーワー ドを使用して, 決算短信PDFから業績要因を含む文 を，再度，抽出する。

本手法では, 2 章の「関連研究」で述べた理由により,一 度, 酒井らの手法で業績発表記事から手がかり表現を抽 出し, 弚れを使用して決算短信PDFから業績要因を含む 文を抽出し, 兴の中から, 再度, 新たな手がかり表現を 獲得する.

\section{$4 \cdot 1$ 業績発表記事からの手がかり表現の自動獲得}

業績要因を含む文の抽出は, まずは, 業績発表記事か ら業績要因表現を抽出した酒井らの手法 [Sakai 08] を適 用し, 業績発表記事から抽出された手がかり表現を決算 短信PDF に使用することで行う，弚のため，まず，業績 発表記事から業績要因を抽出するための手がかり表現を 抽出する酒井らの手法について簡単に述べる.

Step 1：少数の手がかり表現（具体的には,「が好調」， 「が不振」の2表現を用いる) を人手で与え, 光れに 係る節を取得する。

Step 2: 取得した節の集合から，光の中で共通して頻繁 に出現する表現を共通頻出表現として, 後述の基準 を用いて抽出する．

Step 3：共通頻出表現が係る節を取得し，光の中から新 たな手がかり表現を，後述の基準を用いて抽出する．

Step 4: 獲得した手がか表現から，产れに係る節を取 得する.

Step 5: Step 2 から Step 4 を, 新たな手がかり表現と共 通頻出表現か獲得されなくなる，もしくは，予め定 めた回数まで繰り返す (図 1 を参照) .

Step 2 では, 手がかり表現に係る節の集合から，適切な 共通頻出表現を選別する.具体的には, 樣々な手がかり 表現に係っている共通頻出表現は適切であるという仮定 に基づき，共通頻出表現が手がかり表現に係る確率に基 づくエントロピーを式 (1) で求め, 光の值が, ある閾值 $T_{e}$ 以上の共通頻出表現を選別する .

$$
H(e)=-\sum_{s \in S(e)} P(e, s) \log _{2} P(e, s)
$$

ここで, 業績発表記事集合において , 


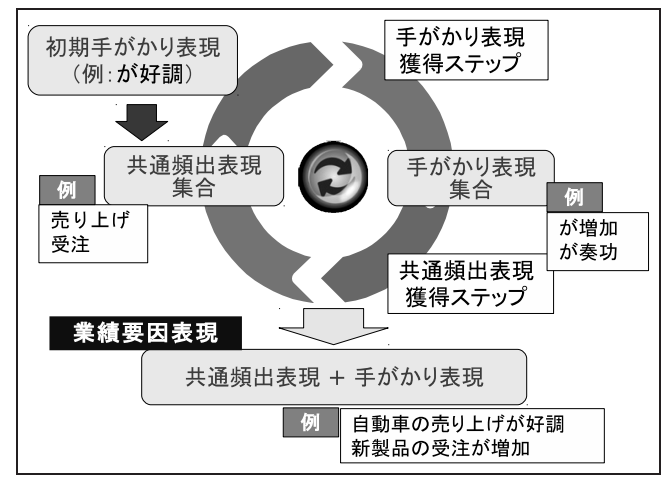

図 1 共通頻出表現・手がかり表現自動獲得手法の概要

$S(e)$ : 共通頻出表現 $e$ が係る手がかり表現の集合 .

$P(e, s)$ : 共通頻出表現 $e$ が手がかり表現 $s$ に係る確率. 式 (2) で求める .

$$
P(e, s)=\frac{f(e, s)}{\sum_{s^{\prime} \in S(e)} f\left(e, s^{\prime}\right)}
$$

ここで, $f(e, s)$ は, 共通頻出表現 $e$ が手がかり表現 $s$ に係る回数である.

エントロピー $H(e)$ は, 共通頻出表現 $e$ が業績発表集合 において樣々な手がかり表現に均一の確率で係っている 場合に高い値をとる。

閾値 $T_{e}$ は，以下の式 (3) によって設定する .

$$
T_{e}=\alpha \log _{2}|N s|
$$

ただし，Ns は共通頻出表現を取得するのに使用した手 がかり表現の集合， $\alpha$ は定数 $(0<\alpha<1)$ である.以下 に，定数 $\alpha$ を 0.50 とした場合に抽出された共通頻出表 現をいくつか示す．

売り上げ, リストラ, 受注量, 電子材料, 部門, 材料 費，採算，人件費，研究開発費

Step 2 で共通頻出表現の抽出を行った後, Step 3 にて , 产の選別した共通頻出表現から新たな手がかり表現を獲 得する.ここでも，樣々な共通頻出表現が係っている手 がかり表現は適切であるという仮定に基づき, 手がかり 表現の選別を行う.具体的には，手がかり表現候補に対 して共通頻出表現が係る確率に基づくエントロピーを求 める .

$$
H(s)=-\sum_{e \in E(s)} P(s, e) \log _{2} P(s, e)
$$

ただし，業績発表記事集合において，

$E(s)$ : 手がかり表現 $s$ に係る共通頻出表現の集合.

$P(s, e)$ : 手がかり表現 $s$ に対して共通頻出表現 $e$ が係 る確率 . 式 (5) で求める .

$$
P(s, e)=\frac{f(s, e)}{\sum_{e^{\prime} \in E(s)} f\left(s, e^{\prime}\right)}
$$

ここで, $f(s, e)$ は, 手がかり表現 $s$ に対して共通頻 出表現 $e$ が係る回数である.
そとて，ある䦨值以上の候補を手がかり表現として抽出 する . 閾値は，共通頻出表現と同樣に式 (3)によって設 定するが， $N s$ は新たな手がかり表現を獲得するのに使 用した共通頻出表現の集合である。

以下に, 定数 $\alpha$ を 0.50 とした場合に獲得された手が かり表現をいくつか示す．

改善する。, 堅調だった, 押し上げた。, 低迷した, 苦 戦した。, 落ち込む, 貢献した。, 急増した, 寄与し た, 膨らんだ,けん引した。, 伸び悩む, 低調だった。

なお, 手がかり表現を獲得するのに使用した業績発表記 事の総数は 71,070 , 文字数の合計は $23,116,606$ であっ た . 獲得された手がかり表現の数は 162 個であった .

\section{$4 \cdot 2$ 決算短信 PDF からのキーワードの抽出}

酒井らの業績要因抽出手法では, 業績要因を「共通頻 出表現」と「手がか表現」の2つの表現を使用して抽 出している [Sakai 08] . しかし, 決算短信 PDF から業績 要因を抽出する場合，業績発表記事から抽出した「共通 頻出表現」を使用することは適切ではない . 酒井らの手 法では, 多くの種類の手がかり表現に係っている共通頻 出表現候補を共通頻出表現として選別しているが, 弚の ためには，業績発表記事中に高い頻度で共通頻出表現が 出現している必要がある. 従って, 共通頻出表現として 「売り上げ」のような一般的な語を抽出することができる が, 商品名や部門名等の, 兴の企業にとって重要なキー ワードでありながら，特定の企業の業績発表記事にのみ 出現しているため出現頻度が低い表現は, 共通頻出表現 として選別されない，例えば「セイコーエプソン」にとっ て重要なキーワードである「デバイス精密機器」「セン サー産業機器」「大判インクジェットプリンター」といっ た語句は業績発表記事には出現せず，従って共通頻出表 現としても獲得されなかった，乥こで，ある企業の決算 短信PDF から業績要因を含む文を抽出する際に, 光の企 業の決算短信PDF から企業ごとに重要なキーワードを抽 出する. 乥して, 共通頻出表現の代わりに光のキーワー ドを使用することで, 適切な業績要因を抽出できるよう にする．

決算短信PDF からのキーワードの抽出は, 企業 $t$ の決 算短信 PDF における名詞 $n$ に対して, 以下の式 (6) で重 み $W(n, S(t))$ を計算することで行う .

$$
W(n, S(t))=T F(n, S(t)) H(n, S(t)) \log _{2} \frac{N}{d f(n)}(6)
$$

ここで，

$S(t)$ ： ある企業 $t$ の決算短信 PDF の集合 .

$T F(n, S(t)): S(t)$ において, 名詞 $n$ が出現する頻度 . $H(n, S(t)): S(t)$ の各決算短信 PDF である $d$ に名詞 $n$ が出現する確率 $P(n, d)$ に基づくエントロピー . 以 
表 1 決算短信 PDF から抽出された企業キーワードの例

\begin{tabular}{l|l}
\hline \hline 企業名称 & 企業キーワード \\
\hline 東芝 & 電子デバイス部門, インフラ部門, デバイス部門, ストレージ, 医用システム事業 \\
大日本印刷 & エレクトロニクス, 印刷事業, 液晶カラーフィルター, 情報コミュニケーション部門 \\
カゴメ & 野菜飲料, 野菜生活, 果美食品, 生鮮トマト, 飲料事業, お茶飲料, 植物性乳酸菌ラブレ \\
エーザイ & 医薬品, アリセプト, パリエット, 医薬品事業, 抗がん剂, 製薬用機械 \\
三菱商事 & 資源関連, 金融事業, エネルギー事業, L N G, 石油, インフラ事業 \\
セイコーエプソン & デバイス精密機器事業, センサー産業機器事業, インクジェットプリンター \\
\hline \hline
\end{tabular}

下の式 (7) によって求める .

$$
H(n, S(t))=-\sum_{d \in S(t)} P(n, d) \log _{2} P(n, d)
$$

$d f(n)$ : 名詞 $n$ を含む決算短信 PDF をもつ企業の数 .

$N$ ：決算短信 PDF を収集した企業の数 .

$W(n, S(t))$ は，情報検索で一般的な $t f \cdot i d f$ 值を，1つ の企業の決算短信PDF の集合を1つの文書とみなして求 め,さらに, 兴の企業の決算短信 PDF 集合においてまん ベんなく出現している場合に高い值をとる尺度を組み合 わせたものである . 従って, $W(n, S(t))$ は, 企業 $t$ の決 算短信 PDF の集合中に多く，かつ，まんべんなく出現し， 他の企業の決算短信PDF には出現していない名詞 $n$ に 対して大きな值が割り当てられる．乥して， $W(n, S(t))$ が，企業 $t$ における $W(n, S(t))$ の平均より大きく，かつ， $\log _{2}(N / d f(n))$ が 1 より大きい名詞を企業Webサイトか ら抽出した共通頻出表現とする。例えば,「決算」や「資 産」といった語は, どの企業の決算短信PDFにも頻出す る語であるため, $T F(n, S(t))$ と $H(n, S(t))$ が大きくな るが, 光のような語の $\log _{2}(N / d f(n))$ は 1 より大きくな らないため,キーワードとして抽出されない，また「人工 皮革」のように「人工皮革」を製造している企業の決算短 信には頻出するような語は, $T F(n, S(t))$ と $H(n, S(t))$ に加え， $\log _{2}(N / d f(n))$ も大きくなるため, キーワード として抽出されやすくなる。

表 1 に, 上記の手法によって, 企業ごとの決算短信 PDF から抽出されたキーワード (以降, 企業キーワードと定 義) をいくつか示す.

\section{$4 \cdot 3$ 手がかり表現と企業キーワードを使用した業績要} 因の抽出

4.1 節で業績発表記事から獲得された「手がかり表現」 と，4.2 節で抽出された企業キーワードを使用して，決 算短信PDFから業績要因を含む文を抽出する . 兴のため に，まずは，決算短信PDFから文を抽出する必要がある． 決算短信 PDF をテキスト情報に変換するには, pdftotext コマンドを使用する．しかし，pdftotext コマンドを使用 して決算短信 PDF をテキスト情報に変換すると，一文の 途中で改行が挿入される. 兴のため, 以下の手法で, 決 算短信 PDF から文を抽出する .
Step 1：決算短信 PDF から変換されたテキスト情報の 改行コードを除去して, 連結する。

Step 2: 連結された文字列を「。」で区切る．

Step 3: 区切られた文字列のうち，500 文字以下の文字 で構成される文字列を文として抽出する．

Step 3 の処理を行った理由は，Step 1 で文字列を連結し た結果，表の中の文字が連結され，多くの文字で構成さ れた文字列が文として抽出されることがあるからである． また，Step 3 における閾値である 500 文字を決定するた めに，25,000 個の決算短信 PDF を対象として, Step 2 の段階で区切られた文字列の長さと, 兴の頻度を調査し た．結果を表 2 に示す．1001 文字を超える文字列の頻

表 2 決算短信 PDF から抽出した文字列の長さと光の頻度

\begin{tabular}{l|rr}
\hline \hline 文字列の長さ & 頻度 & 割合 $(\%)$ \\
\hline $1-100$ & 2807467 & 64.04 \\
$101-200$ & 976353 & 22.27 \\
$201-300$ & 211354 & 4.82 \\
$301-400$ & 103983 & 2.37 \\
$401-500$ & 52324 & 1.19 \\
$501-600$ & 32780 & 0.75 \\
$601-700$ & 24791 & 0.55 \\
$701-800$ & 17792 & 0.41 \\
$801-900$ & 13233 & 0.30 \\
$901-1000$ & 11517 & 0.26 \\
1001 以上 & 132290 & 3.02 \\
\hline \hline
\end{tabular}

度が増えている理由は，表中の文字が連結されたためで あると考える .ここで, 文の長さが 500 文字までで光の 割合が $95.44 \%$ となり，表中の文字が連結された文字列 を除去しつつ，大部分の文字列を文として認定できるの で, 500 文字とした .

決算短信PDFから抽出した文に対し，業績発表記事か ら抽出した手がかり表現と決算短信PDFから抽出した企 業キーワードを使用して，業績要因を含む文を抽出する． 以下に手法を示す。

Step 1：業績発表記事から，手がかり表現（「好調だつ た」など）を含む文を抽出する．

Step 2: Step 1で取得された文を係り受け解析し, 手が かり表現を含む文節を取得する。 
Step 3: Step 2 で取得した文節に係っている文節を取得 し，連結する。

Step 4: Step 3 の処理を，係り元の文節がなくなるまで 繰り返す。

Step 5: 連結された文節に企業キーワード（「半導体製 造装置」など) が含まれていた場合, 谷の文を業績 要因を含む文として抽出する (図 2).

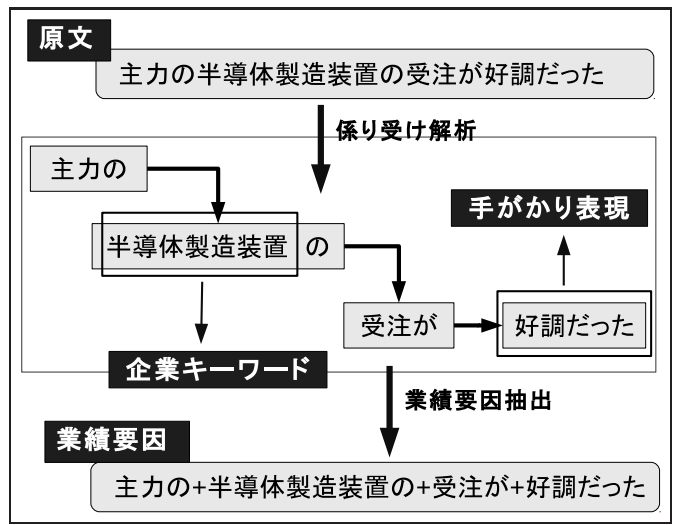

図 2 手がかり表現と企業キーワードを使用した業績要因の抽出

表 3 表 4 に , 決算短信 PDF から抽出された業績要因を 含む文をいくつか示す．

$4 \cdot 4$ 決算短信 PDF からの手がかり 表現の抽出と 業績要 因の抽出

業績発表記事から抽出した手がかり表現と企業キーワー ドを使用して , 決算短信PDF から業績要因を含む文を抽 出し，抽出した業績要因を含む文集合に対して，4.1節で 示した手がかり表現の自動獲得手法を適用する.(最初に 与える手がかり表現は「が好調」「が不振」である.) 上 記の処理を行った結果，以下のような手がかり表現を新 たに決算短信 PDFから取得した. 取得した手がか表現 の数は 121 個であった .

増加いたしました，低迷いたしました，伸び悩みま した，拡大しました，推移いたしました，減少いた しました，堅調でありました

業績発表記事から抽出した手がかり表現と企業キーワー ドを使用して決算短信PDFから抽出した業績要因を含む 文には，例えば以下のような重文が多く存在していた .

鋳造用工業炉は、海外向けアルミ給湯炉が好調に推 移し、輸入機械販売も堅調でありました。

この文には「が好調」といった業績発表記事から獲得し た手がかり表現とともに、堅調でありました」といった 新たに取得できる手がかり表現も含まれている .このよ うな重文が多く存在しているため, 新たな手がかり表現 を得ることができた 。
業績発表記事から獲得された手がかり表現に加え, 新 たに決算短信 PDF から獲得された手がかり表現を使用 し，さらに企業キーワードを使用して，再度，決算短信 PDF から業績要因を含む文を抽出する．業績要因を含む 文の抽出手法は，4.3 節の手法と同樣である. 使用する手 がかり表現の数は, 重複を除去して 225 個であった .

本手法により，例えば,キヤノンの決算短信 PDF から 「コンパクトデジタルカメラの市場は, スマートフォン等 の普及の影響により，低価格モデルを中心に引き続き縮 小か続くと見込んでおります」という文が業績要因とし て抽出された (手がかり表現は「続く」, 企業キーワー ドは「デジタルカメラ」「スマートフォン」など）.この ような文は将来の観測を述べた文であり，業績要因では ない，乥こで，このような明らかに業績要因を含まない 文を除外するために，以下の表現を文末に含む文を除外 した。

- 将来の観測

考えます，見込んでおります，見込みです，予 定です, 可能性があります.可能性もあります， 見通しです，見通しであります

•記載についての注記

省略しております, 以下のとおりであります， 以下のとおりです

-今後の予定

必要があります, 目指してまいります, 実現し ていきます, 所存であります, 所存です, 努め てまいります, 努めていきます

これらの文を除去した理由は以下のとおりである . 本手 法は業績要因を含む文を, 業績発表記事や決算短信 PDF から自動的に獲得した手がか表現を用いて抽出してい る.しかし，自動的に獲得した「手がかり表現」だけで は業績要因を含む文であるかの判別が困難であった事例 がある. 例えば本手法では「推移する」という手がかり 表現か油出されるが,「推移」という語句は, 業績要因を 含む文に頻出する語句であり，文末が「販売が低調に推 移しました」であると業績要因を含む文となる．しかし， 「推移する予定です」「推移する可能性があります」とな ると「将来の観測」になってしまい, 業績要因を含む文で はなくなる，同樣に,「増加」という語句も，業績要因を 含む文に頻出する語句だが, 顧客数の増加を目指してま いります」となると「今後の予定」となってしまい，業績 要因を含む文ではなくなる.このように, 自動的に獲得 した「手がかり表現」を使用しただけでは判別が困難で あつた事例として「将来の観測」「記載についての注記」 「今後の予定」があり，これらを除去した . 
表 3 ソニーの決算短信 PDF から抽出された業績要因を含む文の例

\begin{tabular}{l|l}
\hline \hline 文例 & この大幅な゙減収は、主に、液晶テレビの販売台数が大幅に減少したことによるものです \\
\hline 企業キーワード & 販売台数, 液晶テレビ \\
手がかり表現 & 減少した \\
\hline \hline
\end{tabular}

表 4 セイコーエプソンの決算短信 PDF から抽出された業績要因を含む文の例

\begin{tabular}{l|l}
\hline \hline 文例 & $\begin{array}{l}\text { 大判インクジェットプリンターは、低価格帯モデルは好調であった一方で、 } \\
\text { 高価格帯モデルの需要は企業の投資抑制が影響し低迷しました }\end{array}$ \\
\hline 企業キーワード & 高価格帯モデル, 大判インクジェツトプリンター \\
手がかり表現 & 低迷し, 好調で \\
\hline \hline
\end{tabular}

\section{5. 実装}

本手法を実装し , 3, 821 社の企業 Web ページから 106,885 個の決算短信 PDF ファイルを取得し, 光れらから業績 要因を含む文を抽出した . 実装にあたり, 決算短信 PDF からの業績要因抽出手法における形態素解析器として $\mathrm{MeCab}^{* 9}$ ，係り受け解析器として CaboCha[工藤 02] を 使用した . また，企業 Web ページからの決算短信 PDF ファイルを取得するための, IR 情報ページの識別におけ るサポートベクトルマシンの実装として $S V M^{L i g h t * 10}$ を 使用した .

\section{6. 評 価}

本手法の評価を以下の方法で行った . まず, 無作為に 選別した 10 社の決算短信 PDF から各社ごとに1つの決 算短信 PDF を選択し，谷の中から業績要因を含む文を人 手で抽出し正解データとする*11．次に，選択した決算短 信 PDF から本手法にて業績要因を含む文を抽出し，光 の業績要因を含む文と正解データの文が一致すれば正解 とし, 精度, 再現率を算出した。評洒結果を表 5 に示す。 表 5 の各項目は , 以下のとおりである .

業績要因文数：決算短信 PDF から本手法によって抽出 された, 業績要因を含む文の数

正解文数：決算短信 PDFから人手によって抽出された，

業績要因を含む文の数

決算短信文数：決算短信を構成している文の数

比較手法として，以下の手法と本手法とを比較する．

本手法1：手がかり表現として, 業績発表記事から獲

得した手がか表現と決算短信 PDFから獲得した手 がかり表現を使用する手法 . 使用する手がかり表現 の数は 225 個

本手法2（決算短信 PDF）：業績発表記事から抽出し

た手がか表現を使用して決算短信 PDF から業績要

因を含む文を抽出し，兴の中から獲得された手がか

り表現を使用する手法 (4.4 節で追加された手がか

*9 http://mecab.googlecode.com/svn/trunk/mecab/doc/index.html

*10 http://svmlight.joachims.org/

*11 業績要因を含む文は, 投資の経験が豊富で決算短信をよく読 んでいる，株式投資歴が約 15 年の評価者が抽出した。
り表現を使用する手法と同等) . 使用する手がかり 表現の数は 121 個

本手法2 ( 業績発表記事) : 手がかり表現として, 酒井 らの手法により業績発表記事から取得した手がかり 表現を使用する手法 (4.3 節までの手法と同等) . 使 用する手がかり表現の数は 162 個

酒井らの手法1：業績発表記事から抽出した手がかり 表現を使用して決算短信 PDF から業績要因を含む 文を抽出することを行わず, 決算短信PDF の全ての 文から酒井らの手法で手がかり表現を獲得する手法 (酒井らの手法を, 弚のまま決算短信 PDF に適用し た手法と同等)

酒井らの手法2 : 企業ごとに決算短信 PDF から抽出し た企業キーワードを使用せず, 企業キーワードの代 わりに決算短信 PDFから取得した共通頻出表現を使

用した手法 (業績要因の抽出手法も含めた酒井らの

手法と同等.手がかり表現は本手法1のものを使用) 評価結果を表 6 に示す.なお，評価結果としては, 評価対 象の全ての企業における精度 , 再現率 (表 5 の「ALL」) と, F 值を示す。

表 6 比較手法との比較

\begin{tabular}{lrrr}
\hline \hline 手法 & 精度 $(\%)$ & 再現率 $(\%)$ & $\mathrm{F}$ 値 \\
\hline 本手法1 & 83.91 & 55.04 & 66.47 \\
本手法2 (決算短信 PDF) & 84.89 & 54.12 & 66.10 \\
本手法2 (業績発表記事) & 88.00 & 40.36 & 55.33 \\
酒井らの手法1 & 68.78 & 59.63 & 63.88 \\
酒井らの手法2 & 54.65 & 64.67 & 59.24 \\
\hline \hline
\end{tabular}

\section{7. 考察}

表 6 より, 本手法 1 は精度 $83.91 \%$ であり，比較手法 である酒井らの手法 1 や酒井らの手法 2 に比べて高い精 度を達成することができた．表 5 の「決算短信文数」よ り，決算短信は平均 177.80 文で構成されており，「正解 文数」より，光の中には平均 21.80 文の業績要因を含む 文が含まれている. 弚れに対し，酒井らか対象とした業 績発表記事では，110 記事を調査したところ，平均 15.89 
表 5 本手法の評価結果

\begin{tabular}{llrrrrr}
\hline \hline 証券番号 & 企業名称 & 業績要因文数 & 正解文数 & 決算短信文数 & 精度 $(\%)$ & 再現率 $(\%)$ \\
1332 & 日本水産 & 10 & 18 & 147 & 100.00 & 55.55 \\
1377 & サカタのタネ & 18 & 21 & 193 & 100.00 & 85.71 \\
2503 & キリンH D & 18 & 20 & 67 & 88.88 & 80.00 \\
2730 & エディオン & 7 & 6 & 224 & 71.42 & 83.33 \\
4674 & クレスコ & 14 & 11 & 138 & 57.14 & 72.72 \\
4911 & 資生堂 & 5 & 17 & 154 & 100.00 & 29.41 \\
6502 & 東芝 & 15 & 24 & 149 & 80.00 & 50.00 \\
6724 & セイコーエプソン & 11 & 31 & 241 & 90.90 & 32.25 \\
6758 & ソニー & 38 & 57 & 369 & 78.94 & 52.63 \\
9477 & K A D O K A W A & 7 & 13 & 96 & 85.71 & 46.15 \\
\hline ALL & & 143 & 218 & 1778 & 83.91 & 55.04 \\
\hline \hline
\end{tabular}

文で構成されており，谷の中には平均 3.85 文の業績要因 を含む文が存在していた . 谷のため, 業績要因を含む文 の割合は決算短信PDF のほうが少なく，酒井らの対象と した業績発表記事より業績要因の抽出か灘しいと考える.

表 6 より，業績発表記事から取得した手がか表現を 使用した本手法 2 (業績発表記事) では, 精度は $88.00 \%$ と高いが再現率が $40.36 \%$ と低く，多くの業績要因を含 む文が抽出されていないことが分かる．これは，業績発 表記事と決算短信PDF では文体が異なり，業績発表記事 から抽出した手がかり表現では抽出できない文が多いか らである. 弚れに対し, 決算短信PDF から取得した手 がかり表現を使用した本手法 2 (決算短信 PDF) では， 精度が $84.89 \%$ と，わずかに低下したものの，再現率は $54.12 \%$ と大幅に高くなっている.例えば，本手法2（業 績発表記事) では「パソコンにつきましても Windows8 の販売不振により低迷いたしました」という業績要因を 含んだ文を抽出できなかった．業績発表記事からは「低 迷した」「低迷する」といった手がかり表現を取得してい たが, 上記の文には, 弚れらの手がかり表現が含まれて いない, 弚れに対し, 本手法 2 (決算短信 PDF) の手法 では「低迷いたしました」が手がかり表現として抽出さ れていたため，この文を抽出することができた . 業績発 表記事は「だ・である調」のような常体で書かれ，決算 短信PDF の文体は「です・ます調」のような敬体で書か れている. 兴のため，業績発表記事から取得した 302 個 の手がか表現も「だ・である調」であるが, これらを 全て人手で決算短信PDF の文体である「です・ます調」 に変更するのは多大な労力を要する . しかしながら , 酒 井らの手がかり表現獲得手法を決算短信PDF に適用する ことで，決算短信PDF から業績要因を含む文を抽出する のに適切な手がかり表現を取得することができた .

酒井らの手法 1 との比較では, 酒井らの手法 1 が精度 $68.78 \%$ であるのに対し，本手法は精度が $83.91 \%$ であ り, 大幅に精度が向上している. 業績発表記事に比べて， 決算短信 PDF は業績要因を含む文の割合が低く，酒井ら
の手法を谷のまま適用しては, 不適切な手がかり表現が 多く獲得されてしまった . 兴のため, 本手法では, 酒井 らの手法で業績発表記事から手がかり表現を抽出し，光 れを使用して決算短信 PDF から業績要因を含む文を抽 出し, 弚の中から新たな手がかり表現を獲得することで， 高い精度を達成することができた .また，酒井らの手法 2 との比較では, 酒井らの手法 2 が精度 $54.66 \%$ である のに対し，本手法は精度が $83.91 \%$ であり，大幅に精度 が向上している.これは, 酒井らの手法 2 は, 共通頻出 表現として「比率」のような, どの企業の決算短信 PDF でも出現する表現を抽出する．弚れらを使用して業績要 因を含む文を抽出すると，例えば「2013 年 3 月末の株主 資本比率は 2012 年 3 月末に比べ 1.90 ポイント増加し, $16.90 \%$ になりました」のような文が抽出される. 兴のた め, 精度が低くなった . 光れに対して, 本手法では, 決算 短信 PDFから抽出した共通頻出表現ではなく, 企業キー ワードを使用することで，企業の業務内容について記述 している文を，業績要因が含まれている文として抽出す ることができた .

しかしながら，本手法における再現率は $55.04 \%$ であ り，まだ抽出できない業績要因を含む文が存在している。 例えば,「セイコーエプソン」の決算短信 PDFからは, 市場は、タブレット型が好調であったものの、ノート型 やデスクトップ型は低迷いたしました」という文を抽出 することができなかった .これは, 手がかり表現として 「低迷いたしました」は獲得されていたが, 企業キーワー ドとして「タブレット」や「ノート」「デスクトップ」と いったキーワードか獲得されていなかったため, 業績要 因を含む文として抽出できなかった「セイコーエプソン」 の決算短信 PDF 集合からは、「タブレット」「ノート」「デ スクトップ」が各 3 回しか出現しておらず, 弚のためス コア $W(n, S(t))$ が小さくなり，企業キーワードとして抽 出できなかった 「セイコーエプソン」はタブレット型 $\mathrm{P}$ Cの製造, 販売も行っているが, 決算短信PDFでは「タ ブレット」のような一般的な語はあまり記述されず，光 
のため, 出現回数が少ないと考える．しかし,「セイコー エプソン」の企業 Web ページ全体においては,「タブレッ 卜」が 205 回 ,「ノート」が 220 回 ,「デスクトップ」が 118 回, 出現していた . 兴のため, 企業 Web ページから も企業キーワードを抽出し, 光れと決算短信PDF から抽 出した企業キーワードと併用することで, 再現率の向上 が可能であると考える .

本研究により，酒井らが作成した業績発表記事から抽 出した業績要因を対象とした検索システム [酒井 13] と 同樣な検索システムを実装し，光れを一般に公開するこ とが可能となった . 今後の展望として, 決算短信 PDF か ら抽出した業績要因を含む文を対象とした決算短信 PDF の検索システムの実装を行うことを挙げる . 図 3 に決算 短信 PDF から抽出した業績要因を含む文を対象とした 検索システムを試作し，兴の検索システムにおいて「太 陽電池」で検索した場合の検索結果を示す．図 3 の検

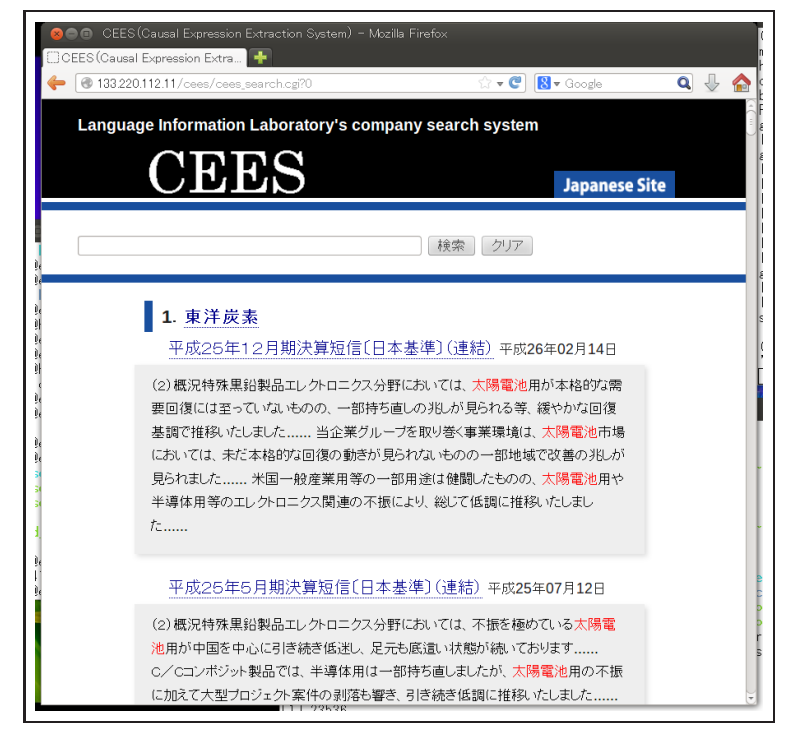

図 3 決算短信 PDF から抽出した業績要因を検索対象とした検索 システムの試作 (「太陽電池」で検索)

索結果では,「東洋炭素」の決算短信 PDF が検索されて いるが，光の他にも「日清紡ホールディングス」や「三 井化学」といった，太陽電池と関連のある企業の決算短 信PDF が検索された . なお，検索される企業の順番は， 企業ごとの決算短信 PDF から抽出した業績要因を含む 文に「太陽電池」を多く含む企業順であり，同一企業の 中での決算短信 PDF の表示の順番は, 新しい日付順とし ている . 本検索システムを使用することで，例えば「太 陽電池」を業績要因にもつ決算短信PDF と光の企業か検 索でき，あるキーワードに関連のある企業を検索するシ ステムとして有効であると考える．弚れにより，例えば 環境意識の高まりから「太陽電池」の技術が注目されて いるときに , 本検索システムを使用することで「太陽電 池」と関連のある企業を検索することが可能となり，投 資先企業の選定に使用できると考える .
また，酒井らは業績発表記事から抽出した複数の業績 要因から重要な業績要因を自動的に認定する手法を提案 している [酒井 13] . この酒井らの手法を決算短信 PDF から抽出した業績要因を含む文に対しても適用し，关の 企業にとって特に重要な業績要因を提示できれば，高度 な専門知識がない個人投資家に対する投資判断支援を行 うための有用な情報源になることが期待できる . 例とし て，図 4 に「三菱電機」の決算短信 PDF から抽出した 業績要因を含む文を示す．試作したシステムでは，決算

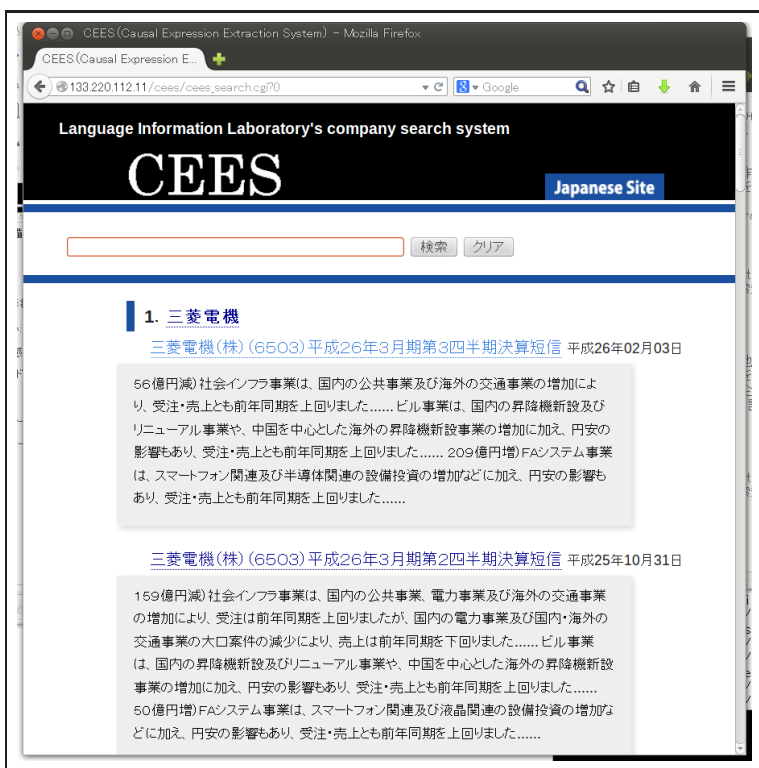

図 4 決算短信PDFから抽出した業績要因表示システムの試作 (「三 菱電機」の決算短信 PDF から抽出した業績要因を表示)

短信 PDF から抽出した業績要因文を並べているだけで あるが , 今後の課題として , 抽出した複数の業績要因文 の中から重要な業績要因文を認定することを行う．さら に, ユーザーが業績要因を理解し株価への影響の判断を 行うには，業績要因による結果，すなわち，業績自身の 情報も必要と考える。これは，決算短信 PDFから，例え ば「売上高及び営業収入は, 前年同期比 $23.90 \%$ 増加の 2 兆 4,128 億円となりました のような業績の情報を抽 出し, 弚の要因として, 本手法で抽出した業績要因を含 む文を示すことができれば，ユーザが業績要因と光の結 果を理解でき，より有用な投資判断支援が可能になると 考える。

\section{8. ま と め}

本論文では, 企業か配布している決算短信PDF を収集 し，兴の決算短信PDF から業績要因を含む文を自動的に 抽出する手法を提案した . まず, 企業の Web ページの中 から決算短信 PDF ファイルがダウンロードできる IR 情 報ページを識別し，企業 Web ページから決算短信 PDF を自動的に取得した。乥して，企業の業績発表記事から 
獲得した業績要因を含む文を抽出するのに有効な手がか り表現と，企業の決算短信 PDF から獲得した企業キー ワードを用いて，決算短信 PDF から業績要因を含む文 を抽出した .さらに，決算短信 PDF から抽出した業績 要因を含む文から，新たに手がかり表現を取得すること で , 多くの業績要因を含む文を抽出した . 本手法を実装 し評価したところ，精度は $83.91 \%$ であり，高い精度を 達成することができた．しかし，再現率は $55.04 \%$ であ り，まだ抽出できない業績要因を含む文が存在していた . 兴のため, 今後の課題として, 企業 Web ゚゚ージからも企 業キーワードを抽出し, 乥れらと決算短信 PDFから抽出 した企業キーワードとを併用することで , 再現率の向上 を試みる。

\section{$\diamond$ 参 考 文 献 $\diamond$}

[Abney 04] Abney, S.: Understanding the Yarowsky Algorithm, Computational Linguistics, Vol. 30, No. 3, pp. 365-395 (2004)

[和泉 11] 和泉 潔, 後藤 卓, 松井藤五郎: 経済テキスト情報を用 いた長期的な市場動向推定, 情報処理学会論文誌, Vol. 52, No. 12, pp. 3309-3315 (2011)

[Koppel 04] Koppel, M. and Shtrimberg, I.: Good News or Bad News? Let the Market Decide, in Proceedings of the AAAI Spring Symposium on Exploring At titude and Affect in Text, pp. 86-88 (2004)

[工藤 02] 工藤 拓, 松本 裕治:チャンキングの段階適用による日本語 係り受け解析, 情報処理学会論文誌, Vol. 43, No. 6, pp. 1834-1842 (2002)

[藏本 13] 藏本 貴久, 和泉 潔, 吉村 忍, 石田 智也, 中嶋 啓浩, 松 井 藤五郎, 吉田 稔, 中川裕志 : 新聞記事のテキストマイニング による長期市場動向の分析, 人工知能学会論文誌, Vol. 28, No. 3, pp. 291-296 (2013)

[Lavrenko 00] Lavrenko, V., Schmill, M., Lawrie, D., Ogilvie, P., Jensen, D., and Allan, J.: Mining of Concurrent Text and Time Series, in Proceedings of the KDD 2000 Conference Text Mining Works hop, pp. 37-44 (2000)

[Milea 10] Milea, V., Sharef, N. M., Almeida, R. J., Kaymak, U., and Frasincer, F.: Prediction of the MSCI EURO index based on fuzzy grammar fragments extracted from European Central Bank statements, in International Conference of Soft Computing and Pattern Recognition, pp. 231-236 (2010)

[Sakai 08] Sakai, H. and Masuyama, S.: Cause Information Extraction from Financial Articles Concerning Business Performance, $I E$ ICE Trans. Information and Systems, Vol. E91-D, No. 4, pp. 959-968 (2008)

[Sakai 09] Sakai, H. and Masuyama, S.: Assigning Polarity to Causal Information in Financial Articles on Business Performance of Companies, IEICE Trans. Information and Systems, Vol. E92-D, No. 12 pp. 2341-2350 (2009)

[酒井 13] 酒井 浩之, 増山 繁 : 企業の業績発表記事からの重要業 績要因の抽出, 電子情報通信学会論文誌 D, Vol. J96-D, No. 11, pp. 2866-2870 (2013)

[Sakaji 08] Sakaji, H., Sakai, H., and Masuyama, S.: Automatic Extraction of Basis Expressions That Indicate Economic Trends, in Pacific-Asia Conference on Knowledge Discovery and Data Mining (PAKDD), pp. 977-984 (2008)

[Yarowsky 95] Yarowsky, D.: Unsupervised Word Sense Disambiguation Rivaling Supervised Methods, in Proceedings of the 33rd Annual Meeting of the Association for Computational Linguistics, pp. 189-196 (1995)

[東京 14] 東京証券取引所 : 決算短信 - 四半期決算短信の作成要 領等 (2014 年 6 月版)，東京証券取引所 (2014)

\section{4 年 5 月 8 日 受理}

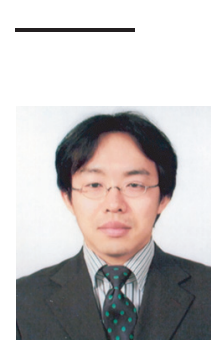

\section{者 紹 介}

\section{酒井 浩之(正会員)}

2005 年 豊橋技術科学大学大学院工学研究科博士後期課程 電子. 情報工学専攻修了. 博士 (工学) . 2005 年 豊橋技術 科学大学 知識情報工学系助手. 2012 年 成蹊大学理工学 部情報科学科講師. 2014 年成䠦大学理工学部情報科学 科准教授、自然言語処理, 特に, テキストマイニング,テ キスト自動要約の研究に従事. 言語処理学会, 電子情報通 信学会, 情報処理学会等会員.

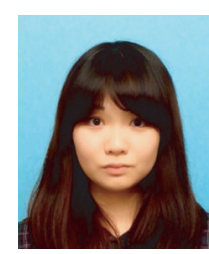

\section{西沢裕子}

2014 年 成蹊大学理工学部情報科学科卒業. 在学中は, 自 然言語処理, 特に, 決算短信 PDF ファイルからの業績要因 抽出の研究に従事。現在，セイコーエプソン株式会社勤務。

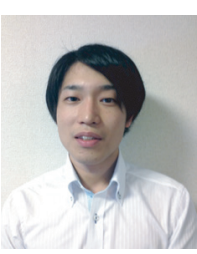

\section{松並 祥吾}

2014 年 成䟾大学理工学部情報科学科卒業. 在学中は, 自 然言語処理，特に，企業 Web ページにおける IR 情報ペー ジの自動識別の研究に従事. 現在, N E Cソリューション イノベータ株式会社勤務。

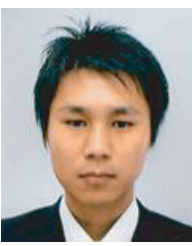

\section{坂地 泰紀(正会員)}

2012 年豊橋技術科学大学大学院工学研究科博士後期課程 電子・情報工学専攻修了. 博士 (工学) . 2012 年 株式会社 ドワンゴ入社. 2013 年 成䟾大学理工学部情報科学科助 教.自然言語処理, 特に,テキストマイニングの研究に従 事、電子情報通信学会, 言語処理学会等会員. 